Fiori dell'anima. La simbologia dei fiori nell'immaginario religioso Flowers of the soul. The symbolism of flowers in the religious imagination a cura di Marco Papasidero e Francesco Galofaro

\title{
Giving and taking life Flower arranging in Howard Nemerov and Medb McGuckian
}

\author{
Anthony John Lappin \\ Independent Scholar, Knivsta, SE \\ gundisalbus@gmail.com
}

\begin{abstract}
The power of flower-symbolism is examined with regard to two very different poets from the latter half of the 2oth century who use petalled plants to deal with fundamentally religious or spiritual values even when explicitly religious language, allegiance or even evocation of the numinous was policed as un-poetic. The poets are distinct in gender, political situation, public acclaim, and style, and they use the motif of flower arranging to explore the virtues, on the one hand, of stoic acceptance, and, on the other, female solidarity; and to deploy, for the first, the concentrated bifurcations of paronomasia to explore the topic, and, for the second, intricate webs of allusion and metaphor to describe both the (female) poet's situation and meditate upon the craft. Both, however, rely on a poetics of indefinition to circumvent censure and rejection.
\end{abstract}

\section{Keywords}

Illness; Death; Childbirth; Creativity; Ikebana

\section{Sommario/Content}

1. Introduction

2. Nemorov

3. McGuckian

4. Conclusion

References 


\section{Ocula ${ }^{23}$}

Vol 21, No 23 (July 2020) • DOI: 10.12977/ocula2020-36

Anthony John Lappin | Giving and taking life. Flower arranging in Howard Nemerov and Medb McGuckian

\section{Introduction}

The two poems analysed here were written within a few years of each other (the first, in 1975; the second, in 1979), and both take as their subject the business of arranging flowers. There, however, the similarities stop, to be replaced by chasms of difference: the first, written by a male poet, assured of both reputation and artistic power, accepted by the poetic and political establishment of the United States; the second, composed by a female poet at the very start of her career, already assailed by opposition from the male poetic establishment, and, as a young Catholic woman in Troubles-era Northern Ireland, doubly marginalized. Perhaps due to such obvious differences of locus the enunciative styles of the poems are starkly different: the first, classical in its pellucidity and detachment, with a penchant for playful puns - there is no doubt what the poem is about; the second, expressing itself through a glass darkly, allusive, thriving on paratactical imagery and abstruse allusion, baroque almost in the multiple meanings it generates, provokes a more visceral reaction, a grasping after meaning, rather than an assured savouring of the poet's skill of conjuring and dispelling meanings. The juxtaposition, too, goes some way to explore the binary nature of much flower-writing within Western literature:flowers as foreboders of death - flowers as inflexions of femininity, eroticism, and life itself. As a more general theme, the poems illustrate the use of flowers in order to approach a religious understanding without recourse to confessional tropes; on the one hand, due to the secular nature of the poet's persona from which he considered fundamentally religious topics; on the other, the subaltern position of the poet, discriminated against because of her sex and religious allegiance. Thus, from one side, we gain an expression of agnosticism accompanied by the refusal to drop the insistent question about survival after death; on the other, a reading through the co-option of an alien tradition, a meditation about the role of community and creativity through (quasi-serious) ritual engagement.

\section{Nemorov}

So to the first, chronologically speaking. It is a fine example of the craft of poetry itself: Howard Nemorov's Flower Arrangements (Nemorov 1975).

Flower Arrangements

The flowers that a friend brings twice a week

for Pat

Or even oftener accumulate

In plastic cups beside me on the table.

Not only I forget to throw them out,

But also I've a curiosity,

Fading a bit myself, to watch them fade.

They do it with much delicacy and style. 


\section{Pcula ${ }^{23}$}

Vol 21, No 23 (July 2020) • DOI: 10.12977/ocula2020-36

Anthony John Lappin | Giving and taking life. Flower arranging in Howard Nemerov and Medb McGuckian

Shrinking into themselves, they keep their cool

And colors many days, their drying and

Diminishing would be imperceptible

But for the instance of the followers

Arranged beside them in the order of

Their severance and exile from the earth;

In death already though they know it not.

At last the petals shrivel, fold and fall,

The colors grow pastel and pale, the stems

Go brittle and the green starts turning brown;

The fireworks are over, and life sinks,

Down in or else evaporates, but where?

From time to time I throw a cup away,

Wondering where lives go when they go out.

The poem is formed of three seven-lined stanzas, marked by some light final-line assonance (stanza I: accumulate - table - fade; II: followers - order of - earth; III: stems - brown - where - out). The poet uses the flowers brought to his bedside by a concerned and assiduous friend to muse upon mortality - indeed, the assiduity of the visits suggests that the self-description, "Fading a bit myself", alludes self-deprecatorily to a much more serious state of health. The plastic cups used to hold the flowers, placed on the table next to him, perhaps suggest a hospital, rather than a homely, setting; and, through their single-use throw-away nature, also suggest impermanence, transience, and eventual disposal. The title, similarly, plays with these ad-hoc containers for the flowers: flower arrangements are usually professionally - or semi-professionally assembled bouquets or wreaths destined, oft-times, to accompany a coffin; and "arrangements" play on funeral arrangements: both the decisions regarding, and the carrying-out of, the ritual valediction of both corpse and the life that inhabited it.

We have thus a poem whose light tone belies its serious intent, and the grave, life-threatening situation which forms its frame. At the same time, its whimsicalness - proper to a communication to a friend; as the epigraph reads, For Pat, perhaps the "friend" that brings the flowers with such regularity prevents any maudlin notes of self-pity or existentialist self-dramatization to creep in, maintaining a playful, allusive wondering about the matter of death, summed up by his affectedly detached "curiosity" about the process by which the cut flowers decay, which partly explains why they accumulate upon this bedside table. The proliferation also suggesting his inability or difficulty, which holds him back from tidying them up, removing the dead, leaving proper space for the fresh: brought and offered as gifts, traditionally, to express the wish that he might getting well (soon), but which turn for him into a means not of bewailing but exploring mortality. Of course. there may be a self-deprecatory tone in this, a recognizing by the poet himself that he is somewhat incapable of disposing of objects, even those well past their sell-by-date. 


\section{Dcula ${ }^{23}$}

Vol 21, No 23 (July 2020) • DOI: 10.12977/ocula2020-36

Anthony John Lappin | Giving and taking life. Flower arranging in Howard Nemerov and Medb McGuckian

The second stanza examines more closely the process of withering and wilting, not as a dramatic decline, but a measured, almost unnoticed process: with his love of paranomasia (see Pettingell 1992: 706-707), the flowers "keep their cool" (they are both not withered by the heat, as well as, in contemporary argot, remaining calm and deliberate before a difficulty or tragedy), "and their colors" (both the intensity of their petals' hues, and, via "true colors", their real essence, their essential characteristics); this alliterative word play is immediately followed by an alliterative contrast working in parallel: drying (against "cool") and diminishing ("colours"). The process is slow, and the poet's awareness of it only comes about because a contrast is constantly offered by the recurring presentation of newly brought fresh flowers, allowing the stages of each individual bloom's trajectory towards its end to be identified and plotted against "the followers" - those that come after, but also those that head in the same direction - ordered by the time of their cutting, the literal meaning of severance (1. 13); yet, with the combination of this word with "exile", the more familiar sense of severance comes to the fore: "the action of ending a connexion or relationship": no longer connected to the earth which gives them life, effectively banished from their homeland, they are ignorant of the fact that they are already dying.

The description does not simply describe the harvesting of blooms, but plays with more traditional conceptions of the meaning of death: the final line of the stanza (1.14) evokes the powerful memento mori tradition, which characterized the act of living as a constant dying as the present was swept away into the "dead" past; yet, at the same time, the demands of living also distract from the realization of one's own mortality; thus one was required to meditate upon that mortality, to bring it to mind regularly, the better to live well (Potts 1994: 68-70). In the same vein, we may note that the fixity of the blossoms and the use made of them for meditation may be related to the practice of depicting flowers in the still life; Nemorov dedicated a "ecphrastic series" of poems to this genre of painting (Costello 2008: 13), and Gillum noted how, for Nemorov, death presented itself both as an inexplicable transformation and as a subject that contained life and beauty (1973: 100-105).

Nevertheless, severance from the earth was precisely the prospect for the souls of the just after the separation from the body (the Platonic definition of death: see Lan 1995), and their ascent to their heavenly reward, returning from their (again, Platonic) exile on the earth. ${ }^{1}$ Here, with the flowers' being "in death", the separation from the earth implied in the ascent of the Platonic soul is re-classified, not as re-birth, or as flight, or as escape, to a new life, but part of a process of decline and disappearance: although they "shrink into

1 Although born to exiled Russian Jews, Nemorov's own interests were drawn to Augustine and the medieval tradition expressed in Dante: see Austerlitz 2010; in the words of Prunty 2003: ix, «Nemerov was a skeptic in dialogue with hope. He cast a longing eye toward neoplatonism, window-shopped the Aristotelian aspects of Aquinas, but ended up viewing America's midcentury aspects through the lens of process philosophy, where formulas were more reliable than forms and the logos was more verb than noun». 


\section{Dcula ${ }^{23}$}

Vol 21, No 23 (July 2020) • DOI: 10.12977/ocula2020-36

Anthony John Lappin | Giving and taking life. Flower arranging in Howard Nemerov and Medb McGuckian

themselves" (cp. 1. 8), turning inward, recoiling from the outside world (as in the "shrinking violet"), this interiority is a product of the definitive separation from life; "into themselves" is also "in death".

The final stanza concentrates on The End; the first three lines (15-17) offer a description of the plant breaking down: the petals' form retracting, colours fading; and, in parallel, the stems' losing their elasticity ("go brittle"-the result of the aging process in pipes, plastics and bones), and their colour changing; the description further held together by the parallel alliterations (fold - fall; pastel - pale; brittle - brown). The process is summarized in the following line (1. 18): "The fireworks are over", an allusion to the brilliant colour of the flowers, true; ${ }^{2}$ but also a phrase to indicate the end of a party or festivity, and end to liveliness; "and life sinks/Down", like the falling petals; and "life sin$\mathrm{ks} / . .$. in", is absorbed, inwards, into the remains of what was the flower, and sinks in, is grasped, finally understood in the acts of death and dissolution; "or else evaporates", the scientific term giving "life" a measurable quality, a material existence which can then be located: "but where?"

This questioning returns us to the bed-side scene: the poet occasionally disposes of the detritus: but now the flowers are no longer referred to, only their containers: "From time to time I throw a cup away" with the same, or perhaps a different, question on his mind: "Wondering where lives go" - the switch from life to the plural lives moves on from the "life" (life-force, existence) that infuses the plant, to turn the spotlight on biographical, human lives, the sum of temporal existence and experience that makes up the person; and, true to his poetics, Nemorov ends with a quibble: "when they go out", that is, when they are extinguished, like a candle, or an electric light, or a firework; or, that is, when they leave a dwelling, going somewhere else, continuing. It would be unfair to dismiss the ending as simply a "pun", since the contrasting potential meaning of the words express the poet's own wondering stance, caught between annihilation and the possibility of something else, something undefined and unspecified, an agnosticism through which one might catch strains of deep stoicism being expressed, even if they have been covered liberally with an overlay of post-existentialist whimsy.

\section{McGuckian}

Medbh McGuckian's “The Flower Master” is amongst the first poems she published, in small pamphlet, Single Ladies: sixteen poems, produced by Interim Press (Salterton and Devon 1980); it became the title-poem of her volume produced by Oxford University Press, in 1982. Another, expanded edition of this collection, with a slightly adapted title, The Flower Master and Other

2 And presumably a nod to the garish taste for bright and clashing colours that had been promulagated by style gurus, such as David Hicks (1929-98), for example in his On living - with taste (1968), which also occupied itself with flower arrangements as part of an overall schema which produced such grievous ocular harm, it can only be understood as both product of excessive consumption of illegal substances, and incentive to continue their incessant use in a domestic setting. See, further, Prendergast (1997). 


\section{Ocula ${ }^{23}$}

Vol 21, No 23 (July 2020) • DOI: 10.12977/ocula2020-36

Anthony John Lappin | Giving and taking life. Flower arranging in Howard Nemerov and Medb McGuckian

Poems was published by Gallery Books eleven years later, after McGuckian's relationship with Oxford University Press had broken down due to heavy-handed and deeply unsympathetic editing. ${ }^{3}$

The Flower Master

Like foxgloves in the school of the grass moon

We come to terms with shade, with the principle

Of enfolding space, our scissors in brocade.

We learn the coolness of straight edges, how

To stroke gently the necks of daffodils

And make them throw their heads back to the sun.

We slip the thready stems of violets, delay

The loveliness of the hibiscus dawn with quiet ovals,

Spirals of feverfew the water splashing.

The papery legacy of bluebells. We do

Sea-foam with sea-lavender, moon-arrangements

Roughly for the festival of moon viewing.

This black container calls for sloes, sweet

Sultan, dainty nipplewort, in honour

Of a special guest who summoned to the

Tea ceremony must stoop to our low doorway,

Our fontanelle, the trout's dimpled feet.

Nemorov's world of affluent safety is far away. The violence that filled the Northern Irish day-to-day profoundly affected McGuckian's work, as explored in relation to this poem most recently by McEvoy (2019). At the same time, and in common with many other Irish poets working during this period, there is a conscious exclusion of the themes of violence, a refusal to poeticise it, so that the world of poetry creates a space beyond the humdrum reality of sectarian tensions. Still, even with that proviso, nothing is obvious in her verse; in the words of John Goodby, her poetry «flaunts an obscurity without parallel among mainstream Irish poets» (2000: 238); in Maria Johnston's opinion (2018: 373), it is «incontestable that such poetry, through its mind-bending twists and turns, has disturbed the landscape of contemporary poetry in Ireland and beyond in ways that have yet to be properly understood». Nevertheless, it is perhaps important to bear in mind in our later discussion Boyle Haberstroh and Christine St. Peter's view (2007: 126) that McGuckian was not so much a rara avis as an exemplar of the writing style of a number of women poets of her time and place, but who are now neglected by the academy.

3 I cite from the Gallery Books edition; I have not been able to compare the text with the earlier versions, but do cite a later presentation copy, at note 13, below. For the publication history, see Flynn (2012). 


\section{Dcula ${ }^{23}$}

Vol 21, No 23 (July 2020) • DOI: 10.12977/ocula2020-36

Anthony John Lappin | Giving and taking life. Flower arranging in Howard Nemerov and Medb McGuckian

"The Flower Master" is very much a statement of poetic intent, its hermetic juxtapositions foretelling many of the techniques of her later verse, and her fundamental intentions in writing. ${ }^{4}$

This poem, too, is concerned with the arranging of flowers - although here the highly stylized Japanese art-form of flower arranging, ikebana, in its most popular twentieth-century school, Sōgetsu (literally grass-moon, ${ }^{5}$ explicitly cited in the first line of the poem), and considers the ramifications of female creativity within a defined, even feminine space, seizing on the freedom provided by a foreign artistic tradition: a major art in Japan, a minor craft in the West; and possessing a much more complex relation to gender in the East than does its European homologue. As excellent Google-sleuthing and an essai in critique génétique by Shane Murphy (1998: 114-119) has shown, even seemingly hermetic expressions obey an artistic purpose, and the reading of the poem can be enriched by carefully picking over the literary objets trouvés that provided the raw materials for much of her poetic output. Further, an important defence of the ordered nature of McGuckian's verse is provided by Molly Bendall (1990) who looks below the self-consciously heterogeneous impression the verse initially makes upon the reader.

We should start our exploration of the poem with its literal level: the poem very simply evokes the experience of attending a series of flower-arranging classes: the learning process moves from first instruction (stanza one), to guided creation (stanza two), to final autonomy and creative judgement (stanza three). At the same time, the feminine connexions of flower-arranging are asserted by comparison with dress-making: cutting into brocade (a costly fabric with, usually, raised flower designs; 1. 3), equated to creating an "enfolding space", which expresses the importance of emptiness within the zen-inspired aesthetics of ikebana; the allusion to slipped stitches in 1.7 ("We slip the thready stems of violets") to produce a ring of flowers, the "quiet ovals" of 1. 8 . Finally, another gendered activity is highlighted in the tea ceremony, the Japanese ritual performed by women, and for which the final decoration would be designed as a centrepiece.

The first stanza provides an introduction to the art, and particularly the concepts of light and space. Like the purple foxgloves (Digitalis purpurea), they must "come to terms with shade": foxgloves grow in shady spots, out of full sun. So must the learners "come to terms", accept, after struggle, and understand the deployment of shade, and with the underlying zen aesthetic principle of empty space, "enfolding" the flower arrangement, forming an important element of the composition itself - in comparison to Western flower-arranging, which has traditionally aimed for a delimited shape fully fil-

4 For a rapid overview of her poetry and the vogues of theory to which it has been subjected, see Stenson (2006). Theoretical jam-making with McGuckian's verse is found, for example, in Han (1996) and Docherty (1992).

5 See, for example, Weiss, A.S. (2013: 45). The grass here is Miscanthius sinensis (or, in an older taxonomy, Eulalia japonica), that is, Japanese pampas grass, also called maiden silvergrass (the latter name may have a bearing on the thematics of the poem). 
led by flowers. ${ }^{6}$ At the same time, being in the shade implies a diminishment: acceptance that one is not centre-stage, in the limelight; the ego is subsumed into both the group (the plural foxgloves) and the art itself. As Inoue (2015: 28-29), observes, from its earliest period ikebana discouraged superficial self-expression, and inculcated an apprenticeship in technique before "reason", even though, eventually, both become equally important. We might say there is even a commonality between the ethos of ikebana and McGuckian's own mode of composition: «the writing process is [...] conceptualized as a passive process, which disregards the will of the creative mind» (Faragó 2014: 16).

And so, in line with this emphasis upon the abnegation of self, the first person plural, "we", "our", is the mode of enunciation throughout the poem. And so the first action is straightening the daffodil (Narcissus, 1. 5) from staring down in self-love at its own reflection (to follow the Greek myth and its subsequent Freudian cross-fertilization): away from the earth and facing up to the sun and the heavens.

This submersion of ego is of one with learning the technique, the slow manipulation of the flower stem's shape to transform it, through gentle massaging and rubbing, bending it according to the pattern sought, and so produce the required effects. Thus the two basic oppositions of form in ikebana are enumerated: vertical straight lines (ll. 4-6), and, in the following stanza, curved lines (ll. 7-8) produced by weaving wreaths of violets, shaping spirals of feverfew, sprays of sea-lavender. Here we see in the symbolism adumbrated - daffodil/sun, violets (Viola odorata)/night, hibiscus/dawn, feverfew (Tanacetum parthenium)/water as it falls, sea-lavender (Limonium scabrum)/ sea-foam - the principles behind some of the earliest ikebana theorization, in that the external universe is reproduced within the flower arrangement: «To create high mountains and deep gulches readily in a small room, and to see grand scenery without going there: this is beyond the other arts».7 This apprenticeship culminates in the "moon-arrangements" for the Japanese mid-harvest festival of Otsukimi, centred around viewing the full (harvest) moon and reproducing it in flower. Yet these arrangements are done "roughly" (l. 12), perhaps without skill or finesse, perhaps - since what is being described is, after all, a class - not on the exact dates of the fertility festival itself (which follows, with regional variations, the Japanese lunar calendar). Roughly, too, because all the plants named are European varieties, evidently with analogues in the Japanese tradition, but not the actual Japanese plants. ${ }^{8}$

6 Although this was not the case for the more outré of interior designers (see above, n. 2) who were experimenting with Japanese forms in characteristically iconoclastic fashion.

7 Fushunken Senkei, Rikka Imayō-sugata (1688), cited by Inoue (2014: 20).

8 For the moon festival, for example, there are seven canonical blooms: hagi (bush clover, Lespedeza), obana (pampas grass: see above, n. 5), nadeshiko (Dianthus japonicus), ominaeshi (Patrinia scabiosaefolia), kuzu (Pueraria lobata), kikyō or bellflower (Platycodon grandiflorus), fujibakama (thoroughwort, Eupatorium fortunei). At least some of the flowers mentioned in the poem bear similarities to their Japanese exemplars: thus Prunus spinosa/blackthorn flowers echo hagi; sweet 


\section{Dcula ${ }^{23}$}

Vol 21, No 23 (July 2020) • DOI: 10.12977/ocula2020-36

Anthony John Lappin | Giving and taking life. Flower arranging in Howard Nemerov and Medb McGuckian

The third stanza begins with the base which forms the support for the arrangement, and which was, in Sogetsu, an integral part of the flower-sculpture. Here the black receptacle is to be combined with the dark purple-black berries of the sharp-spiked blackthorn (Prunus spinosa); the large mauve, explosive flowers of Amberboa moschata, in turn contrasting with the small yellow flowers of Lapsana communis. Again, the formation of the arrangement is not an ego-trip of creative brilliance: it is the container which "calls for" - both "creates an obligation to provide" and also "demands": the arrangement is not an imposition upon the vase, but a completion in harmony with its nature; the vase is, also, the only object or person to be given a speaking role in the poem. This combination of vase, drupes and flowers is to be created for a "special guest", presumably the Sōgetsu-master for whom the poem is titled, who is "summoned" to another Japanese ritual, the tea ceremony, yet must in courtesy bow, "stoop to our low doorway", their lack of expertise or high standards, their infancy ("our fontanelle"), even their unevolved primitiveness (the trout's feet are fins, for fins eventually evolved into feet).

Yet there is still an attempt to recreate a Japanese scene within a Western context. Etymologically, a fontanelle is a small fountain, a spring, or, by extension, a pool, such as those in an ideal Japanese tea-garden, filled with fish. The image perhaps extrapolates from the "pools" of water in which the flower arrangements are fixed. The fish, though, are not multi-coloured Japanese carp (as one might expect at a tea ceremony), but, European like the flowers, a trout, whose "dimpled feet" evoke the shape of fins, dimpled in the webbing between their spines that form them; furthermore, floating close to the surface, the trout's upper fins will dimple the water, displaying its presence in the enfolding space, the water of its existence.

Critics have, however, been much more enthralled by the traces of sexuality or eroticism in the poem, placing the artistic aspect of flower-arranging in a decidedly second rank. Even whilst we recognize the flirtatious eroticism of the poem, it is still important to respect the structure of the poem, how it lays out a progress in an art, the gaining of a form of mastery over its techniques and its philosophy. One of the difficulties faced by the critic who approaches the poem and is sensitive to the eroticism, however, particularly if that critic is male, is the difficulty of reconciling this evident sensuality with the first person plural, which runs against the Western lyric tradition of lover and beloved, a one-on-one which must exclude others. In the last lines of the first stanza, the drooping daffodil becomes erect by the stroking of its neck (and the narcissus flower, whilst still in its spathe, is most decidedly phallic) - but it is "we" who learn this, the class, working together. The poet is not depicting herself alone,

sultan/Amberboa moschata, nadeshiko; nipplewort/Lapsana, ominaeshi; foxgloves/ Digitalis purpurea, kuzu; and the bluebell - if referring to the Scottish bluebell, Campania rotundifolia (simply called bluebell in both Scotland and parts of Northern Ireland) -, kikyō; the common bluebell, Hacinthoides non-scripta, however, may be indicated by the word-play "papery legacy" (1. 10). The use of European blooms was championed by Ohara Unshin during the Meiji period, and continues as a significant force within Japanese ikebana (cf. Steere 1972: 123). 
Anthony John Lappin | Giving and taking life. Flower arranging in Howard Nemerov and Medb McGuckian

providing intimate erotica for an unnamed other. Rather there is the humour of innuendo, and (more importantly) an assertion of female control exerted over the male sexual response, just as the ovals of violets "delay" the phallic stamen of the hibiscus: the night-sky symbolized by the oval of dark petals elongating the night, deferring the day. ${ }^{9}$ The black container has been almost universally equated with the womb; yet this itself demands the astringent and spiky sloe, contrasting with the sweet sultan, completed by the suggestively named nipplewort, all to be placed (shamelessly?) on display.

Similarly the tea ceremony, another female activity, performed by women, generally to honour a (male) guest - we might see a parallel with ikebana, which had become a primarily female activity, often presided over by male masters (although, at least in Sōgetsu, female masterhood was not unenvisaged, and the founder's daughter, Kasumi Teshigahara, took a crucial role in the formation of artists and led the movement after her father's death in 1979). ${ }^{10}$ Yet the authority figure, the "special guest" is not invited: he is "summoned"; he does not come of his own accord, but is obliged to attend the women's ceremony. He must "stoop" (and in a sense, humiliate himself) not only to the low doorway, but to "our fontanelle, the trout's dimpled feet" - these are, as we have already seen, a multivalent pair of images, to whose freight we may attribute an erotic, or perhaps it would be better to say generative, current. ${ }^{11}$

The trout is a symbol of perhaps magical fertility, used in "Gateposts", a poem which came to be included in the final form of the collection: "She tosses stones in basins to the sun, | And watches for the trout in the holy well" (McGuckian 1993a; see Flynn 2012: 425; Collins 2015: 142). The low doorway might well be equated with the female pudenda, the opening in "nether regions", "down there" (as the euphemisms would have it), which is placed immediately in apposition to "our fontanelle" or soft spot; the fontanelle is the space between the baby's cranial bones that allow for compression of the head during natural delivery; this "low doorway" (in the first sense) does not fuse and close with adulthood, but instead renders possible conception and birth itself. As Wills (1993: 160) observes, McGuckian's poetry foregrounds "the bodily and corporeal nature of the meanings of motherhood" (although it does not, at least explicitly, oppose them in quite the confrontational manner Wills assumes).

9 From very early within the tradition of ikebana, the circle symbolized the heavens: Inoue (2014: 25). And is there a wink towards the well-known association of violets with lesbianism (see, for example, Weiss, A. 1992: 2-3), which had become common currency from the end of the nineteenth century (Gatton 1992: 262-263)?

10 For her biography, see Sogetsu Ikebana Organisation 2010. Kasumi trained her neice, Akane Teshigahara, who now leads the school. Up until the Meiji government of the late nineteenth century, ikebana was almost exclusively a male art form in Japan; it was then appropriated as something particularly fitting for "good wives and wise mothers", turning it into a hybrid: practised mainly by women, initially overseen by a limited and reducing number of men (Ohi 1962: 32-33; Guth 1997: 39). Khon Choi Lee (1995: 141-142) points to the continuing popularity amongst Japanese housewives of the ikebana developed during the Meiji revival, and particularly the Sōgetsu school.

11 Cp. Brazeau (2004), who argues that McGuckian's poetry attempts to destabilize ideological discourses that limit the autonomy of women in Northern Ireland. 


\section{Dcula ${ }^{23}$}

Vol 21, No 23 (July 2020) • DOI: 10.12977/ocula2020-36

Anthony John Lappin | Giving and taking life. Flower arranging in Howard Nemerov and Medb McGuckian

That early conception, the baby-to-be-born, the embryo, is a fish with dimpled feet. This is not so weird, at least not for the late seventies. In the (erroneous) words of the then-authority on childrearing, Dr Spock, "as the baby lies in the amniotic fluid of the womb, he [sic] has gills like a fish" (Spock 1957: 223); ${ }^{12}$ and, about five-six weeks after its conception, shows the dimpled extremities to limbs that will develop into fingers and toes. We have thus a direct evocation of the feminine power of producing new life, linked directly to the creative process of flower-arranging, not an individual attribute, but shared, communal: our is specified on the last line. This direct link provides a superiority of sorts, a superiority over the male "masters", which simply expresses a natural order, in the way that ikebana reproduces the natural forms of flowers. The link is even deeper, since ikebana means "giving life to flowers", or, in the further definition by the founder of the Grass-Moon school, Sofu Teshigahara, "flowers become human in ikebana" (Teshigana 2010).

We might summarize the poem as an expression of female control over this process of "giving life", including of the male "masters" that may take part in it; $;^{13}$ although "control" is the wrong word; and perhaps "curation" would be better. As Collins (2015: 144) says, "The maternal instinct recorded by the poet does not emphasize only the childbearing capacity of the body but rather its entire creative nature» (and, further, in the same line of thought, Sullivan 2004; 2005: 106; Wills 1988).

It thus is perhaps no surprise that her later poetry has been described as a "palimpsest", a conflation of various voices into her own, the act of composition that of "unmooring words from the work of others" (Johnston 2018: 373). As McGuckian (1993b) herself wrote in the year the second edition of The Flower Master appeared,

The female poet's basic problem is an anxiety of authorship; a radical fear that she cannot create, that because she can never become a 'precursor', the act of writing will isolate or destroy her ... Her battle is not against her (male) precursor's reading of the world but against his reading of her. In order to define herself as an author she must

12 Spock was the go-to author for expectant mothers during the latter half of the twentieth century; here he was merely reproducing a common misconception of the period: the "gills" were properly referred to (at the time) as "gill-slits" by analogy with fish; more accurately, they are now referred to as "pharyngeal pouches". For Spock's importance, see inter alia Graebner (1980); Jenkins (1998).

13 One should note that any male elements that do occur are invariably given positive associations: the "gentle" handling required by the daffodil, "the loveliness of the hibiscus dawn", "special guest”, even, perhaps, "sweet | Sultan”. Michael Allen (1992: 289-290) makes much of the capitalization of the latter, in his attempt to cram in a male, equal partner to the poem and so return its eroticism to a normative heterosexual partnership. On a technical note, the poet's own (rather careless) presentation copy held by University College Dublin (<https://digital.ucd.ie/view/ucdlib:46209>) eschews line-initial majuscules, and so "Sultan" may well be a preference more of the printer than the poet. Regarding the poem's thematics, however, the eroticism is much more diffuse than Allen would wish it, much more playful, and much more communally feminine. If, as Hillary Rodham Clinton (1996) learnt from Africa, "it takes a village to raise a child", we might observe that it takes a whole ikebana class to conceive one. 


\section{Dcula ${ }^{23}$}

Vol 21, No 23 (July 2020) • DOI: 10.12977/ocula2020-36

Anthony John Lappin | Giving and taking life. Flower arranging in Howard Nemerov and Medb McGuckian

redefine the terms of her socialisation. ... Frequently, moreover, she can begin such a struggle only by actively seeking a female precursor.

\section{Conclusion}

We have ended on a note of meta-reference. The art of flower-arranging is also a means of creating poetry by reflecting on the nature of the art of poetry. This also holds true for Nemorov, who affects a detached intimacy which is decidedly not earthy. Whilst McGuckian is, in a sense, world-building, evoking and creating a communal understanding rooted in allusion, elision, nods and winks, Nemorov seems much more haphazard, responding to events and processes through ambiguous comment. As Prunty (2003: XI) acutely observed, Nemorov appears to be playing a game, an adversarial game like tennis, where it is important that the ball should be returned, should not go past one's racket: «for Nemerov, the afterlife was a perennial object of debate, if not belief. It was a hope to be batted over the locutionary net, a pursuit whose charm derived more from the motion of the thought than from any conclusions drawn». Combined with Nemorov's self-definition as an "agnostic Jew" (ibidem), we might suspect that Nemorov himself enjoyed playing on both sides of the net, the absence of any definitive commitment to either side a crucial element of his poetics - the definitive commitment was only to an elegantly maintained equipoise, a stance which underlay his acceptability to widely differing groups of readers.

At the same time, though, both the flowers as they waste away, and their depiction by the poet, express a fundamental passivity, a carefully-evoked theoretical aporia. Engagement is kept to a minimum. And the artistry is concentrated on appearing to say more than is actually said. McGuckian, on the other hand, is concentrated on what she can do with the flowers. The doing, however, no less than Nemorov, is carefully calibrated. The evocations of femininity, or perhaps better female generativity and creativeness, avoid the highly confessionalized allegiances of the Northern Irish political situation, where a campaign for civil rights had steered the Protestant ascendency into violent repression and a sporadic civil war, and Catholics were placed between the rigorously patriarchal structures of Church or Irish Republican Army. McGuckian can only adumbrate a shared femininity through the un-confessionalized space of a Japanese cultural form, which has no links to Christianity of any stripe. Just as Nemorov uses the aporia of paronomasia to avoid situating himself withing the philosophical questions he raises, McGuckian can use "the language of flowers" to avoid the crucial Northern Irish question of confessional identity and express some form of traditional spirituality (the importance of womanhood, motherhood, of the nurturing, erotic and creative female) outside narrowly-defined religious terms. In the words of Lesley Wheeler (2003: 498), «a traditional understanding of maternity blossoms into a radically experimental poetics. She investigates subversive possibilities within confined gardens and traditionally feminine spaces». 


\section{Ocula ${ }^{23}$}

Vol 21, No 23 (July 2020) • DOI: 10.12977/ocula2020-36

Anthony John Lappin | Giving and taking life. Flower arranging in Howard Nemerov and Medb McGuckian

\section{References}

Allen, Michael

1992 “The Poetry of Medbh McGuckian”, in Andrews E. (a cura di), Contemporary Irish Poetry, London, Macmillan, pp. 286-309.

Austerlitz, Saul

2010 "Jewish American Poetry: is there something uniquely Jewish about the poetry of Jewish Americans?", My Jewish Learning, at <www.myjewishlearning. com/article/jewish-american-poetry/> [last accessed 5 May 2020].

Bendall, Molly

1990 "Flower Logic: the poems of Medbh McGuckian", The Antioch Review, 48, pp. 367-371.

Boyle Haberstroh, Patricia; St. Peter, Christine

2007 Opening the Field: Irish Women, texts and contexts, Cork, Cork University Press.

Brazeau, Robert

2004 "Troubling Language: avant-garde strategies in the poetry of Medbh McGuckian”, Mosaic, 37, pp. 127-144.

Collins, Lucy

2015 Contemporary Irish Women Poets: memory and estrangement, Liverpool, Liverpool University Press.

Costello, Bonnie

2008 Planets on Tables: poetry, still life and the turning world, Ithaca, Cornell University Press.

Docherty, Thomas

1992 "Initiations, Tempers, Seductions: postmodern McGuckian", in Corcoran N. (a cura di), The Chosen Ground: essays on contemporary poetry of Northern Ireland, Bridgend, Seren, pp. 191-210.

Faragó, Borbála

2014 Medbh McGuckian, Lanham (Maryland), Bucknell University Press.

Gatton, John Spalding

1992 Natalie Clifford Barney: Adventures of the Mind, translated with annotations, Oxford, Oxford University Press.

Flynn, Leontia

2012 "Domestic Violences: Medbh McGuckian and Irish Women's Writing in the 1980s", in Brearton F., Gillis A. (a cura di), The Oxford Handbook of Modern Irish Poetry, Oxford, Oxford University Press, pp. 419-434.

Gillum, John Michael

1973 Mind, World and Word in the Poetry of Howard Nemerov, University of Wisconsin.

Goodby, John

2000 Irish Poetry since 1950: from stillness into history, Manchester, Manchester University Press. 


\section{Ocula ${ }^{23}$}

Vol 21, No 23 (July 2020) • DOI: 10.12977/ocula2020-36

Anthony John Lappin | Giving and taking life. Flower arranging in Howard Nemerov and Medb McGuckian

Graebner, William

1980 "The Unstable World of Benjamin Spock: Social Engineering in a Democratic Culture, 1917-1950", The Journal of American History, 67, 1980, pp. 612-629.

Guth, Christine

1997 "Some Reflections on the Formation of the Meiji Artistic Canon", in Hardacre H., Kern A.L. (a cura di), New Directions in the Study of Meiji Japan, Leiden, Brill, pp. 35-41.

Han, Eunwon

1996 “A Possibility of Women’s Writings: a study of Medbh McGuckian’s poems in the context of J. Kristeva's theory", English Language and Literature, 42, 1996, pp. 791-811.

Hicks, David

1968 On living - with taste, London, Leslie Frewin.

Inoue, Osama

2014 "Nature and Art in Ikebana", International Journal of Ikebana Studies, 2, 2014, pp. 17-30.

2015 "Shugyo Theory in Ikebana”, International Journal of Ikebana Studies, 3, 2015, pp. 27-38.

Jenkins, Henry

1998 “The Sensuous Child: Benjamin Spock and the Sexual Revolution”, in Jenkins H. (a cura di), The Children's Culture Reader, New York, New York University Press, pp. 209-230.

Johnston, Maria

2018 "Medbh McGuckian", in Dawe G. (a cura di), The Cambridge Companion to Irish Poets, Cambridge, Cambridge University Press, pp. 373-386.

Lan, Conrado Eggers

1995 “Body and Soul in Plato’s Anthropology”, Kernos, 8, 1995, pp. 107-112.

Lee, Khon Choi

1995 Japan: between myth and reality, Singapore, World Scientific.

McEvoy, Tara

2019 "Bearing Witness to the Body: Medbh McGuckian's 'The Flower Master' and Paul Muldoon's ‘Quoof”, Australasian Journal of Irish Studies, 18, 2019, pp. $63-76$.

McGuckian, Medbh

1980 "The Flower Master", in The Flower Master and Other Poems, Oldcastle (County Meath), Gallery Books, $1993^{3}$, p. 41.

1982 The Flower Master, Oxford, Oxford University Press.

1993a “Gateposts", in The Flower Master and Other Poems, Oldcastle (County Meath), Gallery Books, $1993^{3}$, p. 35.

1993b "Birds and their Masters", Irish University Review, 23.1, 1993, pp. 29-33.

Murphy, Shane

1998 “'You Took away My Biography': The Poetry of Medbh McGuckian”, Irish University Review, 28, 1998, pp. 110-132. 


\section{Ocula ${ }^{23}$}

Vol 21, No 23 (July 2020) • DOI: 10.12977/ocula2020-36

Anthony John Lappin | Giving and taking life. Flower arranging in Howard Nemerov and Medb McGuckian

Nemorov, Howard

1975 "Flower Arrangements", Poetry (August), p. 272.

Ohi, Onobu

1962 History of Ikebana, Tokyo, Shifunotomo.

Pettingell, Phoebe

1992 "Knowledge Turning into Dream: recollections of Howard Nemerov", The Sewanee Review, 100, 1992, pp. 706-715.

Potts, Dana L.

1994 Howard Nemerov and Objective Idealism: the influence of Owen Barfield, Missouri, University of Missouri Press.

Prendergast, Sara

1977 "Hicks, David (Nightingale): British interior and furnishings designer", in Prendergast S. (a cura di), Contemporary Designers, London, St James' Press, pp. 365-367.

Prunty, Wyatt

2003 "Foreword", Selected Poems of Howard Nemorov, Ohio, Swallow, pp. IX-XIV.

Rodham Clinton, Hillary

1996 It Takes a Village: and other lessons children teach us, New York, Simon \& Schuster.

Sogetsu Ikebana Organization

2010 "The Iemotos: Kasumi”, at <www.sogetsu.or.jp/e/about/iemoto/kasumi/> [last accessed 5 May 2020].

Spock, Benjamin

1957 Baby and Child Care, New York, Cardinal.

Steere, William Campbell

1972 Flower Arranging: the ikebana way, New York, Madison Square Press.

Stenson, Sara E.

2006 "Medbh McGuckian (1950-)”, in González A.G. (a cura di), Irish Women Writers,Westport, Greenwood, pp. 200-208.

Sullivan, Moynagh

2004 “The In-formal Poetics of Medbh McGuckian”, Nordic Irish Studies, 3, 2004, pp. 75-92.

2005 “'Dreamin' My Dreams With You': Medbh McGuckian and the Theatre of Dreams”, Metre, 17, 2005, pp. 100-111.

Teshigana, Akane

2010 "Message", in Fourth Headmaster of Sogetsu School of Ikebana, at <www.sogetsu.or.jp/e/about/iemoto/> [last accessed 5 May 2020].

Weiss, Allen S.

2013 Zen Landscapes: perspectives on Japanese gardens and ceramics, London, Reaktion. 


\section{Dcula ${ }^{23}$}

Vol 21, No 23 (July 2020) • DOI: 10.12977/ocula2020-36

Anthony John Lappin | Giving and taking life. Flower arranging in Howard Nemerov and Medb McGuckian

Weiss, Andrea

1992 Vampires and Violets: lesbians in cinema, London, Johathan Cape.

Wheeler, Lesley

2003 "Both Flower and Flower-Gatherer: Medbh McGuckian's 'The Flower Master' and H.D.'s 'Sea Garden”, Twentieth-Century Literature, 49, 2003, pp. 494519 .

Wills, Claire

1988 "The Perfect Mother: authority in the poetry of Medbh McGuckian", Text and Context, 3, 1988, pp. 91-111.

Anthony John Lappin è nato a Liverpool nel 1968. Ha studiato a Oxford, dove ha conseguito il dottorato in studi medievali. Ha insegnato nelle università di Oxford, Manchester, Maynooth (dov'è stato per quattro anni professore di ricerca) e Uppsala. Ha pubblicato numerose ricerche su temi storici tra la tarda antichità e l'età contemporanea. Tra le sue più recenti pubblicazioni, due studi sulla tradizione manoscritta di John Donne (Baroquely Valedicting: Donne forbidding mourning, «Studia neophilologica» 2019 e A Hymne? To God the Father?, «Variants» 2020). Vive in Svezia. 